\title{
Cytokine gene polymorphisms and serum cytokine levels in patients with idiopathic pulmonary fibrosis
}

Esam H Alhamad ${ }^{1,4^{*}}$, Joseph G Cal ${ }^{1}$, Zahid Shakoor ${ }^{2}$, Adel Almogren ${ }^{2}$ and Ahmad A AlBoukai ${ }^{3}$

\begin{abstract}
Background: Studies have demonstrated associations between cytokine gene polymorphisms and the risk of idiopathic pulmonary fibrosis (IPF). We therefore examined polymorphisms in the genes encoding interleukin (IL)-6, IL-10, interferon gamma (IFN- $\gamma$ ), tumor necrosis factor alpha (TNF-a), and transforming growth factor-beta 1 (TGF- $\left.\beta_{1}\right)$, and compared the serum levels of these cytokines in IPF patients and healthy controls. Furthermore, we examined the association of the studied genotypes and serum cytokine levels with physiological parameters and the extent of parenchymal involvement determined by high-resolution computed tomography (HRCT).

Methods: Sixty patients with IPF and 150 healthy controls were included. Cytokine genotyping was performed using the polymerase chain reaction sequence specific primer (PCR-SSP) method. In a subset of patients and controls, serum cytokine levels were determined by enzyme-linked immunosorbent assay.

Results: There was no difference between IPF patients and controls in the genotype and allele distributions of polymorphisms in TNF-a, IFN- $\gamma$, IL-6, IL-10, and TGF- $\beta_{1}$ (all $p>0.05$ ). The TNF-a (-308) GG, IL-6 (-174) GG and CG, and IL-10 (-1082, -819, -592) ACC ATA genotypes were significantly associated with HRCT scores (all $p<0.05)$. IL-10 $(-1082,-819,-592)$ ACC haplotype was associated with the diffusion capacity of the lung for carbon monoxide, and ATA haplotype was associated with the partial pressure of oxygen $\left(\mathrm{PaO}_{2}\right)$ (all $\left.p<0.05\right)$. The TGF- $\beta_{1}$ (codons 10 and 25) TC GG, TC GC, CC GG and CC GC genotypes were significantly associated with the $\mathrm{PaO}_{2}$ and HRCT scores $(p<0.05)$. The TGF- $\beta_{1}$ (codons 10 and 25$)$ CC GG genotype (5 patients) was significantly associated with higher $\mathrm{PaO}_{2}$ value and less parenchymal involvement (i.e., a lower total extent score) compared to the other TGF- $\beta_{1}$ genotypes ( $81.5 \pm 11.8 \mathrm{~mm} \mathrm{Hg}$ vs. $67.4 \pm 11.1 \mathrm{~mm} \mathrm{Hg}, p=0.009$ and $5.60 \pm 1.3$ vs. $8.51 \pm 2.9, p=0.037$, respectively). Significant differences were noted between patients $(n=38)$ and controls $(n=36)$ in the serum levels of IL-6 and IL-10 (both, $p<0.0001$ ), but not in the levels of TNF-a and TGF- $\beta_{1}$ (both, $p>0.05$ ).

Conclusion: The studied genotypes and alleles do not predispose to the development of IPF but appear to play an important role in disease severity. Our results suggest that the TGF- $\beta_{1}$ (codons 10 and 25) CC GG genotype could be a useful genetic marker for identifying a subset of IPF patients with a favorable prognosis; however, validation in a larger sample is required.
\end{abstract}

Keywords: Idiopathic Pulmonary Fibrosis, Polymorphisms, Genotype, Cytokine

\section{Background}

Idiopathic pulmonary fibrosis (IPF) is a specific form of chronic, progressive fibrosing interstitial pneumonia of unknown cause. It occurs primarily in older adults, and is associated with the histopathological and/or radiological pattern of usual interstitial pneumonia [1]. The pathogenesis

\footnotetext{
* Correspondence: esamalhamad@yahoo.com

'Departments of Medicine, King Saud University, Riyadh, Saudi Arabia

${ }^{4}$ Pulmonary Division, Department of Medicine (38), College of Medicine, King

Saud University, P.O. Box 2925, Riyadh 11461, Saudi Arabia

Full list of author information is available at the end of the article
}

of IPF is complex and remains poorly understood. The initiation of the fibrotic response may depend upon genetic factors and environmental triggers, and $\mathrm{T}$ helper (Th)-1 or Th- 2 cell-derived cytokines may be important. More specifically, there may be an imbalance between pro- and anti-fibrotic/inflammatory cytokines and growth factors such as tumor necrosis factor-alpha (TNF- $\alpha$ ), transforming growth factor-betal (TGF- $\beta_{1}$ ), interleukin (IL)-1Ra and IL-6 [2]. The frequencies of polymorphisms in the genes encoding IL-1Ra, TNF- $\alpha$, IL-4, and IL-6 have been 
reported to be increased in patients with sporadic IPF, and polymorphisms of IL- 6 and TGF- $\beta_{1}$ have been associated with disease progression [3-9].

Pulmonary function tests and high-resolution computed tomography (HRCT) are valuable tools for evaluating patients with IPF. In addition, extent of parenchymal involvement scores (as determined by HRCT) are important prognostic markers in IPF patients [10,11]. A previous study noted that poor scores for total extent of fibrosis, honeycombing, reticulation and architectural distortion (all of which reflect advanced stage fibrosis) were significantly associated with increased mortality among Saudi IPF patients [11].

Against this background, we examined polymorphisms in the genes encoding IL-6, IL-10, interferon gamma (IFN- $\gamma$ ), TNF- $\alpha$, and TGF- $\beta_{1}$ among Saudi patients newly diagnosed with IPF, and compared our results with those from healthy volunteers. The serum levels of IL-6, IL-10, TNF- $\alpha$ and TGF- $\beta_{1}$ were also determined among IPF patients and controls. Furthermore, we examined the associations of the studied genotypes and serum cytokine levels with physiological parameters and the extent of parenchymal involvement determined by HRCT.

\section{Methods}

\section{Study population}

Sixty patients with IPF and 150 healthy volunteers solicited from among the hospital personnel as control subjects were included in this study, which was performed between January 2009 and May 2011 at King Khalid University Hospital, King Saud University, Riyadh, Saudi Arabia. The study was approved by the Institutional Review Board/ Ethics Committee of the College of Medicine, King Saud University, Riyadh, Saudi Arabia. Written informed consent was obtained from each individual included in the study. IPF was diagnosed according to the American Thoracic Society/European Respiratory Society consensus classification [12]. Histopathological evidence of IPF was available for $24(40 \%)$ of patients, while the remaining patients were diagnosed on the basis of compatible clinical, laboratory and HRCT findings. Healthy controls were randomly selected and had no associated medical illness. All subjects were evaluated as outpatients, and none had clinical evidence of concurrent infection. None of the patients was receiving any corticosteroids or other immunosuppressive medications at the time of blood sample collection. In addition, none of the patients had any history of acute exacerbations of IPF within three months of the serum cytokine measurements.

Thirty patients seen during the study period were excluded because although their HRCT images were consistent with usual interstitial pneumonia, they had positive autoantibodies based on serological tests. These exclusion criteria included antinuclear antibody titer $>320$, rheumatoid factor titer $>60$, and/or the presence of anti-cyclic citrullinated peptide, anti-Ro/SSA, anti-La/SSB, anti-double-stranded DNA (dsDNA), anti-Smith, antiSclero 70 (Scl-70), anti- ribonucleoprotein (RNP), and anti-histidyl-tRNA synthetase (Jo-1).

\section{Measurements}

Pulmonary function tests (PFT Masterscreen; Jaeger, Hoechberg, Germany) were performed using standard methodologies, including spirometry, plethysmography, and measurement of the diffusion capacity of the lung for carbon monoxide (DLco) [13-15]. Arterial blood gas values (Rapid Lab 865; Bayer, Plymouth, UK) were obtained for the partial pressure of oxygen $\left(\mathrm{PaO}_{2}\right)$, the partial pressure of carbon dioxide $\left(\mathrm{PaCO}_{2}\right)$, and the extent of oxygen saturation $\left(\mathrm{SaO}_{2}\right)$.

\section{Chest HRCT}

All patients underwent CT scanning (Light Speed 16 or VCT XT; GE Medical Systems, Milwaukee, WI, USA). Full-volume scans reconstructed every $2.5 \mathrm{~mm}$ were obtained throughout the entire thorax. Scans were performed during suspended inspiration with patients in the supine position. Additional limited scans using $1.25-\mathrm{mm}$ thin collimation at $10-\mathrm{mm}$ intervals from the aortic arch level to the lung bases, with high spatial resolution reconstruction, were obtained at end-expiration with patients in the prone position. CT images were assessed for the presence and extent of parenchymal abnormalities, including ground-glass opacity, reticular opacity, honeycombing, traction bronchiectasis, emphysema, and architectural distortion. The extent of parenchymal abnormality was determined for each complete lung using a previously described 5-point scale [16] $(0=$ no involvement; $1=1-25 \%$; $2=26-50 \% ; 3=51-75 \%$; and $4=76-100 \%$ ). Each lung was scored separately and divided into three zones (upper zone, lung apex to aortic arch; middle zone, aortic arch to a position inferior to the pulmonary veins; and lower zone, from the inferior pulmonary veins to the diaphragm). A mean score for each of the six zones was calculated for each parenchymal pattern (i.e., ground-glass opacity, reticular opacity, honeycombing, traction bronchiectasis, emphysema, and architectural distortion). Total lung involvement was determined by summing the scores for each CT pattern (total extent).

\section{DNA extraction from peripheral blood}

Peripheral blood $(8 \mathrm{ml})$ was drawn and centrifuged with an acid-citrate-dextrose (ACD) anti-coagulant. DNA extraction was performed using a QIAamp DNA mini kit (Qiagen Inc., Valencia, CA, USA) in accordance with the manufacturer's instructions. In brief, cells were lysed with lysis buffer and proteases, the DNA was ethanol precipitated, and the sample was transferred to a QIAamp column and 
washed twice with washing buffer and centrifugation. To increase the DNA yield, $200 \mu \mathrm{l}$ of elution buffer was added to the column and the sample was incubated for 5 minutes at room temperature. Finally, the DNA was collected by centrifugation for 1 minute. The concentration and purity of the recovered DNA were assessed by spectrophotometry (GeneQuantII, Pharmacia Biotech, Sweden), and the sample was stored in elution buffer at $-20^{\circ} \mathrm{C}$ until use.

\section{Cytokine genotyping}

The investigated gene polymorphisms included TGF- $\beta_{1}$ (codons 10 and 25), IL-6 (-174), IL-10 (-1082, -819 and -592), TNF- $\alpha(-308)$, and IFN- $\gamma(+874)$. Cytokine genotyping was performed using the polymerase chain reaction sequence specific primer (PCR-SSP) method with a cytokine-genotyping tray (Micro SSP ${ }^{\mathrm{max}}$ primer set tray; One Lambda Inc., Canoga Park, CA, USA). DNA samples were thawed at room temperature and mixed with D-mix and recombinant Taq polymerase. The mixture was dispensed to the tray and amplification was performed in a thermocycler (Perkin Elmer 9700; Perkin Elmer, Foster City, CA, USA) using the following program: denaturation at $96^{\circ} \mathrm{C}$ for 2 minutes, 9 cycles of $96^{\circ} \mathrm{C}$ for 10 seconds and $63^{\circ} \mathrm{C}$ for 50 seconds, and then 20 cycles of $96^{\circ} \mathrm{C}$ for 10 seconds, $59^{\circ} \mathrm{C}$ for 50 seconds and $72^{\circ} \mathrm{C}$ for 30 seconds. The amplified DNA products were resolved by electrophoresis and identified using a gel-documentation system (Alpha Inotech, Santa Clara, CA, USA).

\section{Serum cytokine assay}

Due to resource limitations, blood samples were collected from the first consecutively enrolled IPF patients $(n=38)$ and healthy controls $(n=36)$. Cytokines were assessed in serum samples by quantitative sandwich immunoassays performed on a fully automated ELISA machine (ETI-Max 3000; DiasORIN S.p.A, Vercelli, Italy) using ELISA kits purchased from R\&D Systems (Minneapolis, MN, USA). Estimation of each cytokine was performed in accordance with the manufacturers' instructions. Briefly, $50 \mu \mathrm{l}$ of assay diluent was dispensed to each well, and $200 \mu \mathrm{l}$ of standard, control or serum sample were added as appropriate. The contents were incubated at room temperature for 2 hours, washed four times with washing buffer, and mixed with $200 \mu \mathrm{l}$ of cytokine conjugate per well. After a further incubation for 2 hours at room temperature, the plate was washed and $200 \mu \mathrm{l}$ of substrate was dispensed to each well. The plate was then incubated for 20 minutes at room temperature, and $50 \mu \mathrm{l}$ of stop solution was added to each well. Optical densities were recorded and the results were expressed in $\mathrm{pg} / \mathrm{ml}$.

\section{Statistical analysis}

Data are presented as proportions, means and standard deviations for normally distributed data, or as median (range) for non-normally distributed data. Allele and genotype frequencies were calculated by direct counting. Observed and expected frequencies were compared using the chi-square test or Fisher's exact test to check for Hardy-Weinberg equilibrium (HWE). Differences between genotype and allele frequencies in IPF patients and controls were analyzed with the chi-square or Fisher's exact tests. Odds ratios and $95 \%$ confidence intervals for relative risks were calculated. One-way analysis of variance (ANOVA) and the Student's $t$-test were used to compare the means of quantitative variables (age, physiological parameters and HRCT scores) in relation to various genotypes and serum cytokines level. For nonparametric data (serum cytokine levels between patients and controls), the Mann-Whitney U test was used. Pearson's and Spearman's correlation coefficients were used for parametric and nonparametric data, respectively, to examine the relationship between serum cytokine levels and quantitative variables. A twosided $\mathrm{p}$ value $<0.05$ was considered statistically significant. All analyses were performed using the Statistical Software Package for the Social Sciences (SPSS, version 16.0; SPSS Inc., Chicago, IL, USA).

\section{Results}

The 150 healthy controls included 75 males and 75 females with a mean age of $30.8 \pm 9.6$ years. Among the 60 IPF patients, the mean age was $61.1 \pm 12.9$ years; there was a slight predominance of males $(33 ; 55 \%)$, and the male-to-female ratio was 1.22:1. The demographic and clinical characteristics of the IPF patients are shown in Table 1. As expected, restrictive ventilatory defects with markedly decreased diffusion capacities of the lung for carbon monoxide were commonly noted among the IPF patients.

The distributions of the observed genotypes were not significantly different from the expected distribution according to HWE (Table 2) (all p > 0.05).

The distributions of the different cytokine genotypes and alleles in the IPF and healthy control groups are shown in Tables 3, 4 and 5. There was no significant difference in the genotype or allele distributions of polymorphisms in TNF- $\alpha(-308)$, IFN- $\gamma(+874)$, IL-6 (-174), IL-10 (-1082, -819 and -592$)$, and TGF- $\beta_{1}$ (codons 10 and 25) between the IPF and healthy control groups (all p > 0.05).

The associations of the studied genotypes/alleles with the physiological parameters and CT scores for the extent of parenchymal abnormalities are shown in Tables 6 and 7.

Patients with the TNF- $\alpha(-308)$ GG genotype had a higher mean score for honeycombing compared to those with the other TNF- $\alpha(-308)$ genotypes $(1.51 \pm 0.61$ vs. $1.17 \pm 0.57$, respectively, $\mathrm{p}=0.036$ ), whereas patients with the TNF- $\alpha(-308)$ AG genotype tended to have a lower honeycombing extent score compared to those with the 
Table 1 Demographic and clinical characteristics of IPF patients and healthy controls

\begin{tabular}{|c|c|c|}
\hline Characteristics & Patients $(n=60)$ & Healthy controls \\
\hline Age at presentation, years & $61.1 \pm 12.9$ & $30.8 \pm 9.6$ \\
\hline Male/Female & $33 / 27$ & $75 / 75$ \\
\hline Disease duration, months & $32.6 \pm 12.9$ & - \\
\hline Ever smoker, n (\%) & $20(33.3)$ & $34(22.6)$ \\
\hline \multicolumn{3}{|l|}{ Baseline PFTs } \\
\hline FVC,\% predicted & $61.7 \pm 21.9$ & - \\
\hline $\mathrm{FEV}_{1}, \%$ predicted & $69.8 \pm 23.8$ & - \\
\hline TLC,\% predicted & $57.5 \pm 18.7$ & - \\
\hline DLco,\% predicted & $38.1 \pm 21.3$ & - \\
\hline \multicolumn{3}{|l|}{ Baseline ABG } \\
\hline $\mathrm{PaO}_{2}, \mathrm{mmHg}$ & $68.6 \pm 11.7$ & - \\
\hline $\mathrm{PaCO}_{2}, \mathrm{mmHg}$ & $41.1 \pm 6.0$ & - \\
\hline $\mathrm{SaO}_{2}, \%$ & $93.9 \pm 3.7$ & - \\
\hline \multicolumn{3}{|l|}{ HRCT scores } \\
\hline Total extent & $8.3 \pm 3.0$ & - \\
\hline Ground glass opacity & $1.4 \pm 0.8$ & - \\
\hline Reticulation & $1.6 \pm 0.7$ & - \\
\hline Honeycombing & $1.4 \pm 0.6$ & - \\
\hline Traction Bronchiectasis & $2.1 \pm 1.0$ & - \\
\hline Architectural distortion & $1.2 \pm 0.8$ & - \\
\hline Emphysema & $0.4 \pm 0.8$ & - \\
\hline
\end{tabular}

Data are presented as means \pm standard deviations or number (with percentages).

Abbreviations: IPF idiopathic pulmonary fibrosis, PFTs pulmonary function tests, $A B G$ arterial blood gas, $F V C$ forced vital capacity, $F E V$, forced expiratory volume in 1 second, $T L C$ total lung capacity, DLco diffusion capacity of lung for carbon monoxide, $\mathrm{PaO}_{2}$ partial pressure of oxygen, $\mathrm{PaCO}_{2}$ partial pressure of carbon dioxide, $\mathrm{SaO}_{2}$ oxygen saturation and $\mathrm{HRCT}$ high-resolution computed tomography.

other TNF- $\alpha(-308)$ genotypes $(1.16 \pm 0.60$ vs. $1.49 \pm 0.59$, respectively, $\mathrm{p}=0.052)$. Furthermore, honeycombing extent score tended to be lower in patients with the TNF- $\alpha(-308)$ A allele versus the $G$ allele $(1.19 \pm 0.56$ vs. $1.44 \pm 0.62$, respectively, $\mathrm{p}=0.055$ ).

The mean ground glass opacity score was significantly higher for the IL-6 (-174) GG genotype versus the other IL-6 $(-174)$ genotypes $(1.58 \pm 0.89$ vs. $1.00 \pm 0.54$, respectively, $\mathrm{p}=0.021)$, whereas the IL-6 $(-174)$ CG genotype was associated with significantly lower ground glass opacity extent scores compared to the other IL-6 $(-174)$ genotypes $(0.91 \pm 0.54$ vs. $1.55 \pm 0.87$, respectively, $\mathrm{p}=0.022)$. Moreover, the IL-6 $(-174) \mathrm{C}$ allele was significantly associated with lower ground glass opacity and reticulation extent scores versus the $G$ allele $(1.05 \pm 0.52$ vs. $1.50 \pm 0.88, \mathrm{p}=0.032$ and $1.26 \pm 0.65$ vs. $1.64 \pm 0.69$, $\mathrm{p}=0.028$, respectively).

Patients with the IL-10 (-1082, -819, -592) ACC ATA genotype had significantly higher honeycombing extent
Table 2 Hardy-Weinberg equilibrium tests for the investigated cytokine gene polymorphisms among the healthy controls

\begin{tabular}{|c|c|c|c|}
\hline Cytokine/genotype & Observed & Expected & ${ }^{*} \mathrm{p}$-value \\
\hline \multicolumn{4}{|l|}{ TNF-a (-308) } \\
\hline AA & 6.0 & 3.5 & 0.274 \\
\hline$A G$ & 25.3 & 30.3 & 0.304 \\
\hline GG & 68.7 & 66.2 & 0.622 \\
\hline \multicolumn{4}{|l|}{ IFN- $-(+874)$} \\
\hline$\pi$ & 23.3 & 22.7 & 0.891 \\
\hline AT & 48.7 & 49.9 & 0.817 \\
\hline AA & 28.0 & 27.4 & 0.897 \\
\hline \multicolumn{4}{|l|}{ IL-6 (-174) } \\
\hline $\mathrm{CC}$ & 6.0 & 2.9 & 0.156 \\
\hline CG & 22.0 & 28.2 & 0.230 \\
\hline GG & 72.0 & 68.9 & 0.612 \\
\hline \multicolumn{4}{|c|}{ IL-10 (-1082, -819, -592) } \\
\hline GCC GCC & 18.7 & 16.0 & 0.542 \\
\hline GCC ACC & 20.7 & 22.4 & 0.674 \\
\hline GCC ATA & 22.0 & 25.6 & 0.497 \\
\hline ACC ACC & 10.7 & 7.8 & 0.472 \\
\hline ACC ATA & 14.0 & 17.9 & 0.345 \\
\hline ATA ATA & 14.0 & 10.2 & 0.286 \\
\hline \multicolumn{4}{|c|}{ TGF- $\beta_{1}$ (codons 10 and 25) } \\
\hline$\pi \mathrm{GG}$ & 31.3 & 26.3 & 0.373 \\
\hline TC GG & 35.3 & 37.6 & 0.719 \\
\hline TC GC & 10.0 & 13.5 & 0.368 \\
\hline CC GG & 18.0 & 12.3 & 0.199 \\
\hline$\Pi \mathrm{GC}$ & 0 & 0 & - \\
\hline$C C G C$ & 4.7 & 8.8 & 0.164 \\
\hline $\mathrm{CC} C \mathrm{C}$ & 0.7 & 1.4 & 0.562 \\
\hline$\pi C C$ & 0 & 0 & - \\
\hline $\mathrm{TC} C \mathrm{CC}$ & 0 & 0 & - \\
\hline
\end{tabular}

Data are presented as percentages.

Abbreviations: TNF- $a$ tumor necrosis factor alpha, IFN- $\gamma$ interferon gamma, IL interleukin and TGF- $\beta_{1}$ transforming growth factor beta 1 .

* Chi-square or Fisher's exact tests were used to compare frequencies between observed and expected genotypes.

scores compared to those with the other IL-10 (-1082, $819,-592)$ genotypes $(1.88 \pm 0.64$ vs. $1.31 \pm 0.58, \mathrm{p}=0.014)$. The IL-10 (-1082, -819, -592) ACC haplotype was associated with higher DLco value compared to the other haplotypes $(43.18 \pm 24.11 \%$ predicted vs. $32.38 \pm 17.99 \%$ predicted, $\mathrm{p}=0.030$ ), and the ATA haplotype was associated with a lower $\mathrm{PaO}_{2}$ than the other haplotypes $(65.58 \pm$ $11.14 \mathrm{~mm} \mathrm{Hg}$ vs. $71.74 \pm 12.12 \mathrm{mmHg}, \mathrm{p}=0.018$ ).

Exploring the association of TGF- $\beta_{1}$ (codons 10 and 25) with physiological parameters and CT scores revealed several significant findings. The TGF- $\beta_{1}$ (codons 10 and 


\begin{tabular}{|c|c|c|c|c|c|}
\hline $\begin{array}{l}\text { Cytokine/ } \\
\text { Genotype/Allele }\end{array}$ & $\begin{array}{c}\text { IPF } \\
(n=60)\end{array}$ & $\begin{array}{l}\text { Healthy } \\
\text { controls } \\
(n=150)\end{array}$ & ${ }^{*} \mathrm{p}$-value & OR & $95 \% \mathrm{Cl}$ \\
\hline \multicolumn{6}{|l|}{ TNF-a $(-308)$} \\
\hline$A A^{a}$ & $4(6.7)$ & $9(6)$ & 0.856 & 0.894 & $0.264-3.020$ \\
\hline$A G^{b}$ & $19(31.7)$ & $38(25.3)$ & 0.392 & 0.732 & $0.380-1.412$ \\
\hline $\mathrm{GG}^{\mathrm{c}}$ & 37 (61.7) & $103(68.7)$ & 0.336 & 1.362 & $0.730-2.544$ \\
\hline A allele ${ }^{d}$ & $27(22.5)$ & $56(18.7)$ & 0.416 & 0.791 & $0.471-1.327$ \\
\hline G allele & $93(77.5)$ & $244(81.3)$ & & & \\
\hline \multicolumn{6}{|l|}{ IFN- $\gamma(+874)$} \\
\hline$\pi^{e}$ & $15(25)$ & $35(23.3)$ & 0.858 & 0.913 & $0.455-1.832$ \\
\hline$A T^{f}$ & $23(38.3)$ & $73(48.7)$ & 0.220 & 1.525 & $0.828-2.810$ \\
\hline$A A^{g}$ & $22(36.7)$ & $42(28)$ & 0.247 & 0.672 & $0.356-1.267$ \\
\hline T allele ${ }^{h}$ & $53(44.2)$ & $143(47.7)$ & 0.588 & 0.868 & $0.567-1.329$ \\
\hline A allele & $67(55.8)$ & $157(52.3)$ & & & \\
\hline \multicolumn{6}{|l|}{ IL-6 (-174) } \\
\hline$C C^{\mathrm{i}}$ & $4(6.7)$ & $9(6)$ & 0.856 & 0.894 & $0.264-3.020$ \\
\hline$C G^{j}$ & $11(18.3)$ & $33(22)$ & 0.708 & 1.256 & $0.588-2.685$ \\
\hline$G G^{k}$ & $45(75)$ & $108(72)$ & 0.733 & 0.857 & $0.432-1.699$ \\
\hline C allele' & $19(15.8)$ & $51(17)$ & 0.885 & 1.089 & $0.612-1.935$ \\
\hline G allele & 101 (84.2) & $249(83)$ & & & \\
\hline
\end{tabular}

Data are presented as number (with percentages).

Abbreviations: TNF- $a$ tumor necrosis factor alpha, IFN- $\gamma$ interferon gamma, IL interleukin, IPF idiopathic pulmonary fibrosis, $O R$ odds ratio, $\mathrm{Cl}$ confidence interval.

*Chi-square or Fisher's exact tests were used to compare frequencies between genotypes and alleles.

${ }^{a} A A$ vs. $G G$ and $A G$ genotypes.

${ }^{\mathrm{b}} \mathrm{AG}$ vs. $\mathrm{AA}$ and $\mathrm{GG}$ genotypes.

${ }^{c} G G$ vs. $A G$ and $A A$ genotypes.

${ }^{\mathrm{d}} \mathrm{A}$ vs. $\mathrm{G}$ allele.

eTT vs. AT and AA genotypes.

${ }^{f} A T$ vs. $A A$ and $T T$ genotypes.

${ }^{g} A A$ vs. $T$ and AT genotypes.

hT vs. A allele.

'CC vs. GG and CG genotypes.

${ }^{\mathrm{j}} \mathrm{CG}$ vs. CC and $\mathrm{GG}$ genotypes.

${ }^{\mathrm{k}} \mathrm{GG}$ vs. $C \mathrm{G}$ and $C C$ genotypes.

${ }^{\prime} \mathrm{C}$ vs. $\mathrm{G}$ allele.

25) TC GG genotype was significantly associated with a higher ground glass opacity extent score compared to the other TGF- $\beta_{1}$ (codons 10 and 25) genotypes (1.75 \pm 0.79 vs. $1.22 \pm 0.83, \mathrm{p}=0.017$ ), and the TGF- $\beta_{1}$ (codons 10 and 25) TC GC genotype was associated with a lower $\mathrm{PaO}_{2}$ than the other TGF- $\beta_{1}$ (codons 10 and 25) genotypes $(55.16 \pm 4.13 \mathrm{~mm} \mathrm{Hg}$ vs. $69.32 \pm 11.59 \mathrm{mmHg}, \mathrm{p}=0.041)$. In contrast, the TGF- $\beta_{1}$ (codons 10 and 25) CC GG genotype was associated with a higher $\mathrm{PaO}_{2}$ and less parenchymal involvement (i.e., a lower total extent score) compared to the other TGF- $\beta_{1}$ (codons 10 and 25) genotypes $(81.50 \pm 11.86 \mathrm{~mm} \mathrm{Hg}$ vs. $67.44 \pm 11.11 \mathrm{~mm}$
$\mathrm{Hg}, \mathrm{p}=0.009$ and $5.60 \pm 1.34$ vs. $8.51 \pm 2.99, \mathrm{p}=0.037$ respectively). The $\mathrm{CC}$ GC genotype was associated with a lower ground glass opacity score compared to the other genotypes $(0.33 \pm 0.57$ vs. $1.49 \pm 0.83, \mathrm{p}=0.02)$, and the TGF- $\beta_{1}$ (codons 10 and 25) $\mathrm{G}$ allele was associated with higher $\mathrm{PaO}_{2}$ values than the $\mathrm{C}$ allele $(69.26 \pm 11.75 \mathrm{~mm}$ $\mathrm{Hg}$ vs. $59.46 \pm 5.82 \mathrm{~mm} \mathrm{Hg}, \mathrm{p}=0.021)$.

Comparisons of serum cytokine levels in patients $(n=38)$ and controls $(n=36)$ are shown in Figure 1 .

Among the IPF patients, the serum levels of IL-6 [median $4.03 \mathrm{pg} / \mathrm{ml}$ (range $0.00-32.35 \mathrm{pg} / \mathrm{ml}$ ), $\mathrm{p}<0.0001$ ] and IL-10 [median $3.56 \mathrm{pg} / \mathrm{ml}$ (range $0.00-12.17 \mathrm{pg} / \mathrm{ml}$ ), $\mathrm{p}<0.0001]$ were significantly higher than those in the healthy controls [median $0.00 \mathrm{pg} / \mathrm{ml}$ (range 0.00 $267.38 \mathrm{pg} / \mathrm{ml}$ ) for IL-6 and median $0.8 \mathrm{pg} / \mathrm{ml}$ (range $0.00-7.56 \mathrm{pg} / \mathrm{ml}$ for IL-10)].

There was no significant difference in the serum levels of TNF- $\alpha$ between the IPF patients and controls [median $3.3 \mathrm{pg} / \mathrm{ml}$ (range $0.00-26.90 \mathrm{pg} / \mathrm{ml}$ and median $10.6 \mathrm{pg} / \mathrm{ml}$ (range $0.00-64.07 \mathrm{pg} / \mathrm{ml}$ ), respectively; $\mathrm{p}=0.499$ ]. In addition, we found no significant difference in the serum levels of TGF- $\beta_{1}$ between IPF patients and controls [median $13.7 \mathrm{pg} / \mathrm{ml}$ (range 0.00 - 253.84 pg/ml) and median $10.2 \mathrm{pg} / \mathrm{ml}$ (range $2.67-37.15 \mathrm{pg} / \mathrm{ml}$ ), respectively; $\mathrm{p}=0.127]$.

The biochemical serum characteristics of the IPF patients and healthy controls in relation to their genotypes (high, intermediate, and low producers) are shown in Table 8 .

The relationship between serum levels of IL-10 and IL-10 haplotype-carrier state were examined. The serum levels of IL-10 were not significantly different among the IPF who carried the GCC haplotype [median $3.56 \mathrm{pg} / \mathrm{ml}$ (range $0.00-11.27 \mathrm{pg} / \mathrm{ml}$ )] compared with the levels in GCC haplotype-negative patients [median $4.50 \mathrm{pg} / \mathrm{ml}$ (range $0.00-12.16 \mathrm{pg} / \mathrm{ml})](\mathrm{p}=0.701)$. Furthermore, no significant difference in the serum levels of IL-10 among the IPF who carried the ACC haplotype [median $3.56 \mathrm{pg} / \mathrm{ml}$ (range $0.00-7.16 \mathrm{pg} / \mathrm{ml}$ )] compared with the levels in ACC haplotype-negative patients [median $4.50 \mathrm{pg} / \mathrm{ml}$ (range $0.00-12.16 \mathrm{pg} / \mathrm{ml})$ ] $(\mathrm{p}=0.281)$. Moreover, no significant difference in the serum levels of IL-10 among the IPF who carried the ATA haplotype [median $3.56 \mathrm{pg} / \mathrm{ml}$ (range 0.00 - $12.16 \mathrm{pg} / \mathrm{ml}$ )] compared with the levels in ATA haplotype-negative patients [median $3.61 \mathrm{pg} / \mathrm{ml}$ (range $0.00-11.27 \mathrm{pg} / \mathrm{ml})$ ] $(\mathrm{p}=0.988)$. Among the healthy controls no significant difference in serum levels of IL-10 were noted in relation to IL-10 haplotypes (data not shown).

Correlation analysis did not show any significant relationship between the studied serum cytokine levels and the physiological parameters or CT scores for the extent of parenchymal abnormalities in our IPF patients (data not shown). 
Table 4 Comparison of genotype, haplotype carrier rate, haplotype carrier frequencies and allele frequencies for IL-10 in IPF patients and healthy controls

\begin{tabular}{|c|c|c|c|c|c|c|}
\hline \multicolumn{2}{|c|}{ IL-10 (-1082, $-819,-592)$} & $\operatorname{IPF}(n=60)$ & Healthy controls $(n=150)$ & ${ }^{*}$ p-value & OR & $95 \% \mathrm{Cl}$ \\
\hline \multicolumn{7}{|c|}{ Genotype } \\
\hline \multicolumn{2}{|c|}{ GCC GCC ${ }^{a}$} & $10(16.7)$ & $28(18.7)$ & 0.844 & 1.148 & $0.519-2.537$ \\
\hline \multicolumn{2}{|c|}{$\mathrm{GCC} A C C^{b}$} & $13(21.7)$ & $31(20.7)$ & 0.853 & 0.942 & $0.454-1.955$ \\
\hline \multicolumn{2}{|c|}{ GCC ATA $^{c}$} & $14(23.3)$ & $33(22)$ & 0.856 & 0.927 & $0.455-1.889$ \\
\hline \multicolumn{2}{|c|}{$A C C A C C^{d}$} & $7(11.7)$ & $16(10.7)$ & 0.811 & 0.904 & $0.352-2.322$ \\
\hline \multicolumn{2}{|c|}{ ACC ATA $^{\mathrm{e}}$} & $8(13.3)$ & $21(14)$ & 1.000 & 1.058 & $0.441-2.540$ \\
\hline \multicolumn{2}{|c|}{ ATA ATA $^{f}$} & $8(13.3)$ & $21(14)$ & 1.000 & 1.058 & $0.441-2.540$ \\
\hline \multicolumn{7}{|c|}{ Haplotype carrier rate } \\
\hline \multicolumn{2}{|c|}{ GCC carriers } & $37(61.7)$ & $92(61.3)$ & 0.964 & 0.986 & $0.533-1.825$ \\
\hline \multicolumn{2}{|c|}{ ACC carriers } & $28(46.7)$ & $68(45.3)$ & 0.861 & 0.948 & $0.520-1.728$ \\
\hline \multicolumn{2}{|c|}{ ATA carriers } & $30(50)$ & $75(50)$ & 1.000 & 1.000 & $0.549-1.820$ \\
\hline \multicolumn{7}{|c|}{ Haplotype frequency } \\
\hline \multicolumn{2}{|l|}{ GCC } & 0.392 & 0.400 & 0.935 & 1.021 & $0.616-1.693$ \\
\hline \multicolumn{2}{|l|}{ ACC } & 0.292 & 0.280 & 0.737 & 0.916 & $0.549-1.528$ \\
\hline \multicolumn{2}{|l|}{ ATA } & 0.316 & 0.320 & 0.993 & 0.998 & $0.602-1.653$ \\
\hline \multicolumn{7}{|l|}{ Allele } \\
\hline \multirow[t]{2}{*}{-1082} & G allele ${ }^{g}$ & 47 (39.2) & $120(40)$ & 0.912 & 0.966 & $0.626-1.489$ \\
\hline & A allele & 73 (60.8) & $180(60)$ & & & \\
\hline \multirow[t]{2}{*}{-819} & C allele $\mathrm{e}^{\mathrm{h}}$ & $82(68.3)$ & $204(68)$ & 1.000 & 1.015 & $0.644-1.600$ \\
\hline & T allele & 38 (31.7) & $96(32)$ & & & \\
\hline \multirow[t]{2}{*}{-592} & C allele & $82(68.3)$ & $204(68)$ & 1.000 & 1.015 & $0.644-1.600$ \\
\hline & A allele & 38 (31.7) & $96(32)$ & & & \\
\hline
\end{tabular}

Data are presented as number (with percentages).

Abbreviations: IL interleukin, IPF idiopathic pulmonary fibrosis, OR odds ratio, Cl confidence interval.

${ }^{*} \mathrm{Chi}$-square or Fisher's exact tests were used to compare frequencies between genotypes and alleles.

${ }^{a}$ GCC GCC vs. other IL-10 genotypes.

${ }^{\mathrm{b}} \mathrm{GCC}$ ACC vs. other IL-10 genotypes.

'GCC ATA vs. other IL-10 genotypes.

${ }^{\mathrm{d}}$ ACC ACC vs. other IL-10 genotypes.

${ }^{\mathrm{e}}$ ACC ATA vs. other IL-10 genotypes.

${ }^{f}$ ATA ATA vs. other IL-10 genotypes.

${ }^{g} \mathrm{G}$ vs. A allele.

${ }^{\mathrm{h}} \mathrm{C}$ vs. T allele.

${ }^{i} \mathrm{C}$ vs. A allele.

\section{Discussion}

In the present study, we observed significant associations between TNF- $\alpha$, IL- 6 , IL-10, and TGF- $\beta_{1}$ polymorphisms and $\mathrm{PaO}_{2}$, DLco and HRCT scores. Furthermore, the serum cytokine levels of IL- 6 and IL-10 were significantly higher in IPF patients compared to healthy controls.

IPF is a disabling fibroproliferative disorder characterized by progressive fibrosis of the interstitial spaces of the lung, resulting in destruction of the normal parenchymal architecture [17]. Despite extensive research, the cause of IPF is still unknown. Substantial evidence in animal models and humans supports the hypothesis that there is an imbalance between Th- 1 and Th- 2 cytokines, with an excess of Th-2 cytokines being associated with the development of lung fibrosis $[2,18,19]$.
IL-10 is a T-cell-derived cytokine of the Th-2 family that is known to suppress inflammation by inhibiting a number of pro-inflammatory cytokines [20]. Moreover, IL-10 has been shown to induce the generation of a high-IL-10-producing subset of CD4+ T cells, called regulatory $\mathrm{T}$ cells, that are capable of down-regulating antigen-specific immune responses [21]. The pro-fibrotic activity of IL-10 is currently under debate, as experimental studies have reported both anti-fibrotic [22] and pro-fibrotic [23] activities. Martinez and colleagues [24] noted that alveolar macrophages recovered from bronchoalveolar lavage (BAL) in patients with pulmonary fibrosis showed increased IL-10 mRNA expression. Notably, however, these patients had lower IL-10 protein levels in their BAL fluid (BALF) compared to healthy control subjects. Our study 
Table 5 Comparison of genotype and allele frequencies for TGF- $\beta_{1}$ in IPF patients and healthy controls

\begin{tabular}{|c|c|c|c|c|c|c|}
\hline \multirow{2}{*}{\multicolumn{2}{|c|}{$\begin{array}{l}\text { Cytokine/genotype/allele } \\
\text { TGF- } \beta_{1} \text { (codons } 10 \text { and 25) }\end{array}$}} & \multirow[t]{2}{*}{ IPF $(n=60)$} & \multirow[t]{2}{*}{ Healthy controls $(n=150)$} & \multirow[t]{2}{*}{${ }^{*} p$-value } & \multirow[t]{2}{*}{ OR } & \multirow[t]{2}{*}{$95 \% \mathrm{Cl}$} \\
\hline & & & & & & \\
\hline$\Pi \mathrm{GG}^{\mathrm{a}}$ & & $24(40)$ & $47(31.3)$ & 0.260 & 0.684 & $0.368-1.274$ \\
\hline $\mathrm{TC} \mathrm{GG}^{\mathrm{b}}$ & & $24(40)$ & $53(35.3)$ & 0.530 & 0.820 & $0.443-1.517$ \\
\hline $\mathrm{TC} G C^{\mathrm{C}}$ & & $3(5)$ & $15(10)$ & 0.289 & 2.111 & $0.588-7.575$ \\
\hline$C C G G^{d}$ & & $5(8.3)$ & $27(18)$ & 0.091 & 2.415 & $0.883-6.602$ \\
\hline$\pi \mathrm{GC}$ & & 0 & 0 & - & & \\
\hline$C C G C^{e}$ & & $3(5)$ & $7(4.7)$ & 0.918 & 0.930 & $0.232-3.723$ \\
\hline$C C C^{f}$ & & $1(1.7)$ & $1(0.7)$ & 0.500 & 0.396 & $0.024-6.435$ \\
\hline$\Pi \mathrm{TCC}$ & & 0 & 0 & - & & \\
\hline TC CC & & 0 & 0 & - & & \\
\hline \multirow[t]{2}{*}{ Codon 10} & T allele ${ }^{g}$ & $75(62.5)$ & $162(54)$ & 0.128 & 1.420 & $0.920-2.191$ \\
\hline & C allele & $45(37.5)$ & $138(46)$ & & & \\
\hline \multirow[t]{2}{*}{ Codon 25} & G allele ${ }^{h}$ & $112(93.3)$ & $276(92)$ & 0.839 & 1.217 & $0.531-2.791$ \\
\hline & C allele & $8(6.7)$ & $24(8)$ & & & \\
\hline
\end{tabular}

Data are presented as number (with percentages).

Abbreviations: TGF- $\beta_{1}$ transforming growth factor beta, IPF idiopathic pulmonary fibrosis, OR odds ratio, $\mathrm{Cl}$ confidence interval;

${ }^{*}$ Chi-square or Fisher's exact tests were used to compare frequencies between genotypes and alleles.

${ }^{\mathrm{a}} \mathrm{TT}$ GG vs. other TGF- $\beta_{1}$ genotypes.

${ }^{\mathrm{b}} \mathrm{TC}$ GG vs. other TGF- $\beta_{1}$ genotypes.

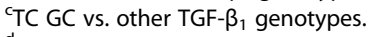

${ }^{\mathrm{d} C C}$ GG vs. other TGF- $\beta_{1}$ genotypes.

${ }^{e} C C$ GC vs. other TGF- $\beta_{1}$ genotypes.

${ }^{f} \mathrm{CC} C \mathrm{C}$ vs. other TGF- $\beta_{1}$ genotypes.

${ }^{9} \mathrm{~T}$ vs. $\mathrm{C}$ allele.

${ }^{\mathrm{h}} \mathrm{G}$ vs. $\mathrm{C}$ allele.

confirms the findings of Tsoutsou et al. [25] that IL-10 is markedly increased in the sera of IPF patients compared to healthy controls. The clinical significance of the high levels of IL-10 observed in IPF patients is unclear, as we found no association between serum IL-10 levels and physiological parameters or the extent of parenchymal abnormalities based on CT scores among the IPF patients. Nevertheless, we found that the IL-10 (-1082, -819, -592) ACC ATA genotype was significantly associated with a higher honeycombing extent score (i.e., a less favorable outcome) compared to the other IL-10 genotypes. In addition, the IL-10 (-1082, -819, -592) ACC haplotype was associated with higher DLco value compared to the other haplotypes, and the ATA haplotype was associated with a lower $\mathrm{PaO}_{2}$ than the other haplotypes. As such, it is possible that IL-10-mediated induction of regulatory $\mathrm{T}$ cells in IPF patients may play a role in the disease process. This will require further investigation.

In agreement with the reports of Riha et al. [6] and Vasakova et al. [8], we found no difference in the distribution of IL-6 alleles or genotypes between IPF patients and controls. IL- 6 displays a broad range of activities, participating in the acute phase response and the stimulation and differentiation of $\mathrm{T}$ and $\mathrm{B}$ cells $[26,27]$. Although most nucleated cells produce IL-6, its secretion by fibroblasts stimulates the proliferation of cells in an autocrine/ paracrine manner, suggesting that IL-6 is one of the key cytokines that promote fibrogenesis [28,29]. Pantelidis et al. [5] noted that the IL-6 intron 4 GG genotype was with lower levels of DLco (as a marker for disease progression) among a cohort of IPF patients from the United Kingdom. In the present study, interestingly, the GG genotype was associated with a significantly higher ground glass opacity score (i.e., active disease) compared to the CG genotype. Furthermore, the IL-6 (-174) C allele was significantly associated with lower ground glass opacity and reticulation scores versus the $G$ allele, implying that IL-6 plays an important role in disease severity. The association between hypoxia and serum IL-6 levels in IPF patients was explored by Tsantes et al. [30], who noted that patients with profound hypoxemia $\left(\mathrm{PaO}_{2}<65 \mathrm{~mm}\right.$ $\mathrm{Hg}$ ) had significantly higher serum IL-6 levels compared to healthy controls. In the present study, we found no differences in IL-6 levels between patients with $\mathrm{PaO}_{2}<$ $65 \mathrm{~mm} \mathrm{Hg}$ or $\mathrm{PaO}_{2}>$ or equal to $65 \mathrm{~mm} \mathrm{Hg}$ (data not shown), suggesting that mechanisms other than hypoxia are involved in IL- 6 secretion in IPF patients. Moreover, we found no correlation between serum IL-6 levels and physiological parameters or CT scores in our IPF patients. However, we observed markedly elevated serum IL-6 levels in IPF patients compared to controls, implying that these patients remain in a persistent inflammatory state 
Table 6 Associations of TNF- $a$, IFN- $\gamma$, and IL- 6 polymorphisms with physiological parameters and HRCT scores in IPF patients

\begin{tabular}{|c|c|c|c|c|c|c|c|c|c|}
\hline \multirow{2}{*}{$\begin{array}{c}\text { Cytokine/genotype/ } \\
\text { Allele }\end{array}$} & \multicolumn{9}{|c|}{ tp-value } \\
\hline & $\overline{\mathrm{PaO}_{2}}$ & FVC, \% P & DLco,\% P & Total extent & GGO & Retic & $\mathrm{HC}$ & $A D$ & Emphy \\
\hline \multicolumn{10}{|l|}{ TNF-a (-308) } \\
\hline $\mathrm{GG}^{\mathrm{a}}$ & 0.670 & 0.397 & 0.663 & 0.214 & 0.348 & 0.361 & $0.036^{*}$ & 0.147 & 0.164 \\
\hline$A G^{b}$ & 0.563 & 0.937 & 0.845 & 0.407 & 0.371 & 0.670 & 0.052 & 0.107 & 0.333 \\
\hline$A A^{c}$ & 0.806 & 0.132 & 0.643 & 0.387 & 0.873 & 0.326 & 0.656 & 0.860 & 0.372 \\
\hline ANOVA & 0.839 & 0.303 & 0.859 & 0.415 & 0.638 & 0.512 & 0.108 & 0.273 & 0.346 \\
\hline$A$ allele ${ }^{d}$ & 0.803 & 0.179 & 0.578 & 0.161 & 0.397 & 0.238 & 0.055 & 0.262 & 0.125 \\
\hline \multicolumn{10}{|l|}{ G allele } \\
\hline \multicolumn{10}{|l|}{ IFN-y (+874) } \\
\hline$\pi^{e}$ & 0.574 & 0.725 & 0.913 & 0.769 & 0.603 & 0.916 & 0.904 & 0.924 & 0.861 \\
\hline$A T^{f}$ & 0.923 & 0.552 & 0.572 & 0.736 & 0.211 & 0.875 & 0.938 & 0.543 & 0.860 \\
\hline $\mathrm{AA}^{\mathrm{g}}$ & 0.547 & 0.360 & 0.652 & 0.939 & 0.430 & 0.950 & 0.852 & 0.484 & 0.983 \\
\hline ANOVA & 0.791 & 0.659 & 0.842 & 0.933 & 0.460 & 0.987 & 0.982 & 0.763 & 0.979 \\
\hline T allele ${ }^{h}$ & 0.443 & 0.392 & 0.808 & 0.896 & 0.824 & 0.982 & 0.838 & 0.586 & 0.925 \\
\hline \multicolumn{10}{|l|}{ A allele } \\
\hline \multicolumn{10}{|l|}{ IL-6 (-174) } \\
\hline $\mathrm{GG}^{\mathrm{i}}$ & 0.236 & 0.654 & 0.346 & 0.138 & $0.021^{*}$ & 0.109 & 0.719 & 0.503 & 0.861 \\
\hline $\mathrm{CG}^{\mathrm{j}}$ & 0.213 & 0.530 & 0.332 & 0.325 & $0.022^{*}$ & 0.502 & 0.674 & 0.663 & 0.686 \\
\hline$C C^{k}$ & 0.901 & 0.844 & 0.860 & 0.300 & 0.659 & 0.083 & 0.198 & 0.626 & 0.351 \\
\hline ANOVA & 0.444 & 0.817 & 0.600 & 0.309 & 0.057 & 0.148 & 0.425 & 0.785 & 0.623 \\
\hline C allele' & 0.288 & 0.777 & 0.379 & 0.078 & $0.032^{*}$ & $0.028^{*}$ & 0.352 & 0.420 & 0.547 \\
\hline $\mathrm{G}$ allele & & & & & & & & & \\
\hline
\end{tabular}

Abbreviations: TNF- $a$ tumor necrosis factor alpha, IFN- $\gamma$ interferon gamma, IL interleukin, HRCT high-resolution computed tomography, IPF idiopathic pulmonary fibrosis, $\mathrm{PaO}_{2}$ partial pressure oxygen, $F V C, \%$ forced vital capacity, percent predicted, DLco diffusion capacity of lung for carbon monoxide, GGO ground glass opacity, Retic reticulation, $H C$ honeycombing, $A D$ architectural distortion, Emphy emphysema.

† One-way analysis of variance (ANOVA) and the Student's $t$-test were used to compare the means of quantitative variables.

* Statistically significant.

${ }^{a} \mathrm{GG}$ vs. AG and $A A$ genotypes.

${ }^{b} A G$ vs. $A A$ and $G G$ genotypes.

${ }^{c} A A$ vs. $G G$ and $A G$ genotypes.

${ }^{\mathrm{d} A}$ vs. $\mathrm{G}$ allele.

eTT vs. AT and AA genotypes.

${ }^{f} A T$ vs. $A A$ and $T$ genotypes.

${ }^{9} A A$ vs. $T$ and AT genotypes.

${ }^{\mathrm{h}} \mathrm{T}$ vs. A allele.

iGG vs. CG and CC genotypes.

${ }^{\mathrm{j}} \mathrm{CG}$ vs. CC and GG genotypes.

${ }^{k} C C$ vs. GG and $C G$ genotypes.

'C vs. G allele.

despite the advanced stage of fibrosis. Recently, Collard et al. [31] noted that serum IL- 6 and other biomarkers of type II alveolar epithelial cells (KL-6 and SP-D) were significantly higher among IPF patients with acute exacerbation compared to stable IPF patients and those with acute lung injury. Together, the findings in the present and previous studies indicate that IL- 6 may be a marker for disease progression. Future studies will be needed to explore its role in the pathogenesis of pulmonary fibrosis.

TGF- $\beta$, which is produced by a wide variety of cell types, is one of the key cytokines involved in the pathogenesis of pulmonary fibrosis. TGF- $\beta_{1}$ possesses a broad spectrum of activities; it is chemotactic for fibroblasts, acts as a potent inducer of extracellular matrix synthesis, and can stimulate protease inhibitor expression [32]. Up-regulation of TGF- $\beta$ gene and protein expression has been documented in lung tissues from patients with IPF and in an animal model of pulmonary fibrosis [33-35]. Furthermore, antibodies against TGF- $\beta_{1}$ were found to decrease bleomycin-induced pulmonary fibrosis, further substantiating the role of this cytokine in pulmonary fibrosis [36]. In studying IPF patients of Han ethnicity, Li et al. [37] found an association between the TGF- $\beta_{1} 869>C$ polymorphism and the development of IPF. In the present study, however, we did not find that 
Table 7 Association of IL-10 and TGF- $\beta_{1}$ polymorphisms with physiological parameters and HRCT scores in IPF patients

\begin{tabular}{|c|c|c|c|c|c|c|c|c|c|c|}
\hline \multirow{2}{*}{\multicolumn{2}{|c|}{$\begin{array}{l}\text { Cytokine/genotype/ } \\
\text { Allele }\end{array}$}} & \multicolumn{9}{|c|}{$t p$-value } \\
\hline & & $\mathrm{PaO}_{2}$ & FVC, \% P & DLco,\% P & Total extent & GGO & Retic & $\mathrm{HC}$ & $A D$ & Emphy \\
\hline \multicolumn{11}{|c|}{ IL-10 (-1082, -819, -592) } \\
\hline \multicolumn{2}{|l|}{$\mathrm{GCC} G C C^{\mathrm{a}}$} & 0.389 & 0.262 & 0.948 & 0.098 & 0.137 & 0.935 & 0.514 & 0.334 & 0.173 \\
\hline \multicolumn{2}{|l|}{$G C C A C C^{b}$} & 0.583 & 0.286 & 0.411 & 0.278 & 0.552 & 0.853 & 0.619 & 0.171 & 0.778 \\
\hline \multicolumn{2}{|l|}{ GCC ATA } & 0.390 & 0.905 & 0.710 & 0.564 & 0.741 & 0.942 & 0.501 & 0.539 & 0.962 \\
\hline \multicolumn{2}{|l|}{$A C C A C C^{d}$} & 0.252 & 0.456 & 0.531 & 0.437 & 0.341 & 0.536 & 0.658 & 0.884 & 0.460 \\
\hline \multicolumn{2}{|l|}{$\mathrm{ACC} \mathrm{ATA}^{\mathrm{e}}$} & 0.533 & 0.354 & 0.390 & 0.171 & 0.837 & 0.069 & $0.014^{*}$ & 0.081 & 0.388 \\
\hline \multicolumn{2}{|l|}{ ATA ATA ${ }^{f}$} & 0.319 & 0.730 & 0.058 & 0.695 & 0.837 & 0.147 & 0.203 & 0.820 & 0.635 \\
\hline \multicolumn{2}{|l|}{ ANOVA } & 0.587 & 0.661 & 0.469 & 0.333 & 0.698 & 0.416 & 0.173 & 0.393 & 0.719 \\
\hline \multicolumn{2}{|c|}{ GCC haplotype ${ }^{g}$} & 0.606 & 0.472 & 0.517 & 0.497 & 0.120 & 0.415 & 0.769 & 0.681 & 0.333 \\
\hline \multicolumn{2}{|c|}{ ACC haplotype ${ }^{\text {h }}$} & 0.312 & 0.293 & $0.030^{*}$ & 0.329 & 0.080 & 0.326 & 0.440 & 0.767 & 0.101 \\
\hline \multicolumn{2}{|c|}{ ATA haplotype' } & $0.018^{*}$ & 0.862 & 0.097 & 0.802 & 0.799 & 0.858 & 0.769 & 0.907 & 0.783 \\
\hline \multirow{2}{*}{-1082} & allelej & 0.461 & 0.499 & 0.830 & 0.438 & 0.144 & 0.876 & 0.996 & 0.881 & 0.200 \\
\hline & allele & & & & & & & & & \\
\hline \multirow{2}{*}{-819} & allele ${ }^{k}$ & 0.053 & 0.841 & 0.066 & 0.941 & 0.914 & 0.542 & 0.617 & 0.793 & 0.988 \\
\hline & allele & & & & & & & & & \\
\hline \multirow[t]{2}{*}{-592} & |llele' & 0.053 & 0.841 & 0.066 & 0.941 & 0.914 & 0.542 & 0.617 & 0.793 & 0.988 \\
\hline & allele & & & & & & & & & \\
\hline \multicolumn{11}{|c|}{ TGF- $\beta_{1}$ (codons 10 and 25) } \\
\hline \multicolumn{2}{|l|}{$\pi G^{m}$} & 0.902 & 0.161 & 0.548 & 0.690 & 0.462 & 0.708 & 0.734 & 0.839 & 0.711 \\
\hline \multicolumn{2}{|l|}{$\mathrm{TC} \mathrm{GG}$} & 0.967 & 0.290 & 0.663 & 0.509 & $0.017^{*}$ & 0.708 & 0.734 & 0.892 & 0.951 \\
\hline \multicolumn{2}{|l|}{ TC GC } & $0.041^{*}$ & 0.119 & 0.217 & 0.876 & 0.240 & 0.528 & 0.270 & 0.732 & 0.444 \\
\hline \multicolumn{2}{|l|}{$\mathrm{CC} \mathrm{GG}$} & $0.009^{*}$ & 0.372 & 0.526 & $0.037^{*}$ & 0.238 & 0.201 & 0.146 & 0.248 & 0.314 \\
\hline \multicolumn{11}{|l|}{$\pi \mathrm{GC}$} \\
\hline \multicolumn{2}{|l|}{$C C G C^{a}$} & 0.128 & 0.858 & 0.101 & 0.412 & $0.020^{*}$ & 0.291 & 0.074 & 0.059 & 0.945 \\
\hline \multicolumn{2}{|l|}{$\mathrm{CCCC}^{\mathrm{r}}$} & 0.911 & 0.083 & 0.539 & 0.451 & 0.090 & 0.403 & 0.533 & 0.122 & 0.050 \\
\hline \multicolumn{11}{|l|}{$\pi \subset C$} \\
\hline \multicolumn{11}{|l|}{ TC CC } \\
\hline \multicolumn{2}{|l|}{ ANOVA } & $0.025^{*}$ & 0.157 & 0.408 & 0.359 & $0.010^{*}$ & 0.586 & 0.246 & 0.210 & 0.382 \\
\hline Codon 10 & T allele $^{\mathrm{s}}$ & 0.662 & 0.076 & 0.441 & 0.315 & 0.319 & 0.543 & 0.701 & 0.760 & 0.738 \\
\hline & C allele & & & & & & & & & \\
\hline Codon 25 & G allele ${ }^{t}$ & $0.021^{*}$ & 0.687 & $0.027^{*}$ & 0.890 & 0.053 & 0.726 & 0.968 & 0.800 & 0.370 \\
\hline & C allele & & & & & & & & & \\
\hline
\end{tabular}

Abbreviations: IL interleukin, TGF- $\beta_{1}$ transforming growth factor beta, $H R C T$ high-resolution computed tomography, IPF idiopathic pulmonary fibrosis, $P a O_{2}$ partial pressure of oxygen, $F V C, \%$ P forced vital capacity, percent predicted, DLco diffusion capacity of the lung for carbon monoxide, GGO ground glass opacity, Retic reticulation, $H C$ honeycombing, $A D$ architectural distortion, Emphy emphysema.

† One-way analysis of variance (ANOVA) and the Student's $t$-test were used to compare the means of quantitative variables.

* Statistically significant.

${ }^{a}$ GCC GCC vs. other IL-10 genotypes.

${ }^{\mathrm{b}} \mathrm{GCC}$ ACC vs. other IL-10 genotypes.

'GCC ATA vs. other IL-10 genotypes.

${ }^{\mathrm{d} A C C}$ ACC vs. other IL-10 genotypes.

${ }^{\mathrm{e}}$ ACC ATA vs. other IL-10 genotypes.

${ }^{f}$ ATA ATA vs. other IL-10 genotypes.

${ }^{9} \mathrm{GCC}$ vs. other IL-10 haplotypes.

${ }^{\mathrm{h}} \mathrm{ACC}$ vs. other IL-10 haplotypes.

'ATA vs. other IL-10 haplotypes.

${ }^{\mathrm{j}} \mathrm{G}$ vs. A allele.

${ }^{\mathrm{k}} \mathrm{C}$ vs. T allele.

'C vs. A allele.

${ }^{\mathrm{m}} \mathrm{T}$ GG vs. other TGF- $\beta_{1}$ genotypes.

${ }^{\mathrm{n}} \mathrm{TC} \mathrm{GG}$ vs. other TGF- $\beta_{1}$ genotypes.

${ }^{\circ} \mathrm{TC}$ GC vs. other TGF- $\beta_{1}$ genotypes.

${ }^{\mathrm{P} C C} \mathrm{GG}$ vs. other TGF- $\beta_{1}$ genotypes.

${ }^{9} \mathrm{CC}$ GC vs. other TGF- $\beta_{1}$ genotypes.

'CC CC vs. other TGF- $\beta_{1}$ genotypes.

${ }^{S} \mathrm{~T}$ vs. $\mathrm{C}$ allele.

${ }^{\mathrm{t}} \mathrm{G}$ vs. C allele. 


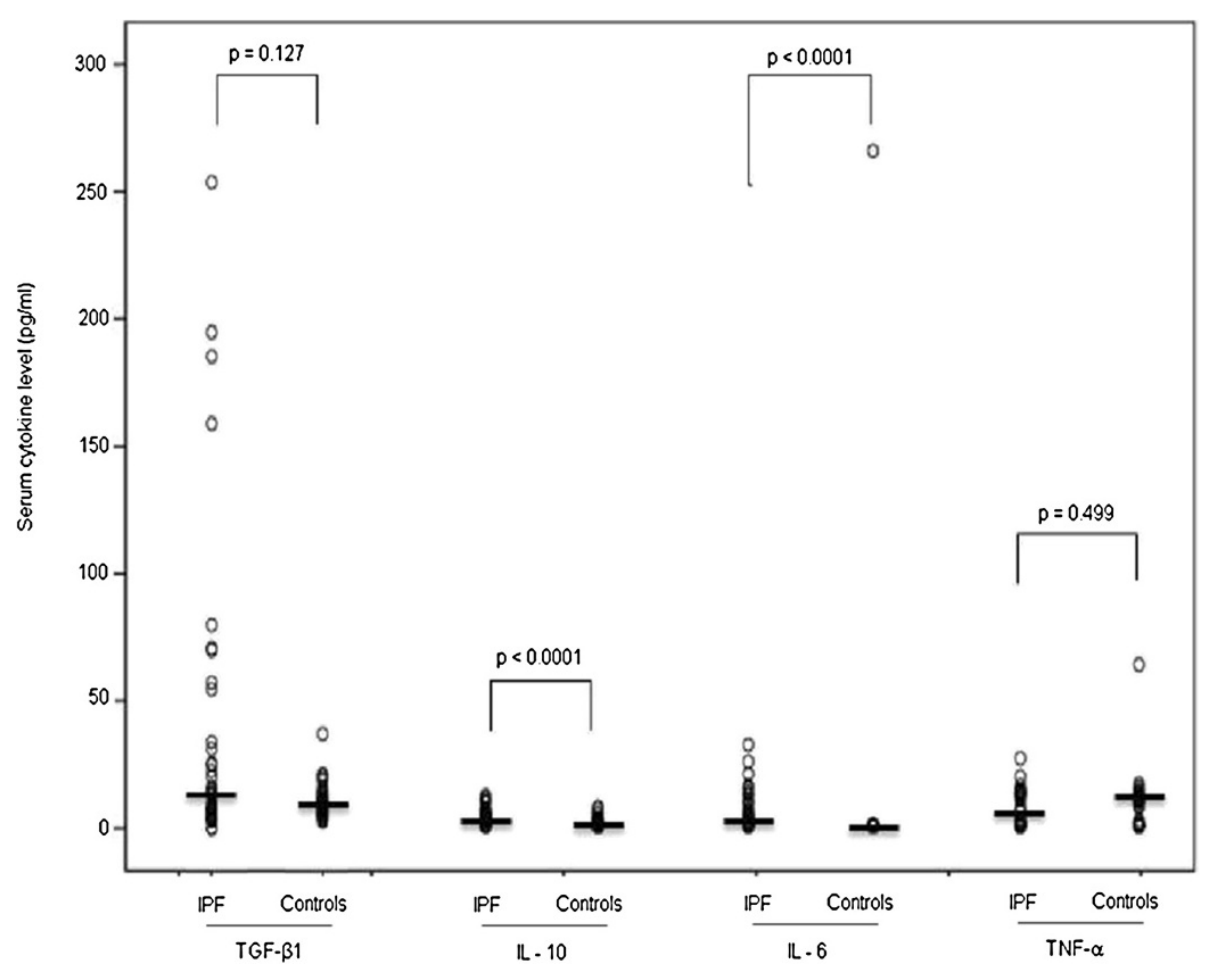

Figure 1 Serum levels of interleukin (IL)-6, IL-10, transforming growth factor-beta 1 (TGF- $\beta_{1}$ ), and tumor necrosis factor alpha (TNF- $\alpha$ ) in idiopathic pulmonary fibrosis (IPF) patients $(\mathbf{n}=\mathbf{3 8})$ and healthy controls $(\mathbf{n}=\mathbf{3 6})$. Each circle represents one individual, and transverse lines indicate median values. P-values were determined using the nonparametric Mann-Whitney $U$ test.

TGF- $\beta_{1}$ gene polymorphisms predisposed Saudi patients to develop IPF. This is in agreement with reports from other regions, including Spanish [9], Australian [6], and Czech [8] populations. Nonetheless, the lack of association between TGF- $\beta_{1}$ gene polymorphisms and the disease does not rule out the clinical importance of this cytokine in the ongoing scarring observed in IPF patients. Xaubet and colleagues [9] noted that the presence of the prolineencoding allele at codon 10 of TGF- $\beta_{1}$ in IPF patients was associated with a significant increase in alveolar arterial oxygen tension difference during follow-up, compared to IPF patients without the proline-encoding allele. In the present study, the associations of the TGF- $\beta_{1}$ (codons 10 and 25) TC GG, TC GC, CC GG, and CC GC genotypes with $\mathrm{PaO}_{2}$ and the extent of parenchymal involvement (as assessed by HRCT) suggest that TGF- $\beta_{1}$ plays an important role in determining disease severity. The CC GG genotype is particularly interesting in this respect, as it was significantly associated with a higher $\mathrm{PaO}_{2}$ value and a lower total extent score. Relatively few patients harbored this genotype $(n=5)$ in the present study, making it difficult to draw a firm conclusion. Future work will be required to validate our findings in a larger sample and examine whether this genotype could be used to identify a subset of IPF patients with a more favorable prognosis.
Plasma levels of TGF- $\beta_{1}$ have been shown to be under genetic control [38]. In IPF patients, the plasma levels of TGF- $\beta_{1}$ were previously noted to be higher than those of controls [39,40]. However, Molina-Molina et al. [39] reported that changes in TGF- $\beta_{1}$ levels did not correlate with changes in lung function parameters in IPF patients monitored over time. Here, we found no significant difference in the serum level of TGF- $\beta_{1}$ between patients and controls. Also, consistent with the previous report [39], the serum levels of TGF- $\beta_{1}$ did not correlate with any clinical parameter (e.g., pulmonary function tests, arterial blood gas values and CT scores) in our IPF patients.

TNF- $\alpha$ is a proinflammatory cytokine that plays a central role in stimulating cell-cell adhesion and transendothelial migration, as well as in the early events of the cytokine and chemokine production cascade [41]. Increased expression of TNF- $\alpha$ has been found in the lung tissues of humans and animal models of pulmonary fibrosis, and administration of a neutralizing anti-TNF- $\alpha$ antibody to an animal model was shown to attenuate pulmonary indicating that TNF- $\alpha$ is an important cytokine in the pathogenesis of lung fibrosis $[41,42]$. TNF- $\alpha$ polymorphisms have been significantly associated with an increased risk of IPF among Italians and Australians, but not in British and Czech populations $[3,5,6,8]$. In the current 
Table 8 Serum cytokine levels in relation to their genotypes and alleles among IPF patients and healthy controls

\begin{tabular}{|c|c|c|c|c|c|c|}
\hline \multirow{2}{*}{$\frac{\text { Cytokine/genotype/ Allele }}{\text { TNF-a }}$} & Producer & $n$ & IPF & $n$ & Healthy controls & *p-value \\
\hline & & & & & & \\
\hline GG & Low & 21 & $1.37(0-19.68)$ & 24 & $11.22(0-64.07)$ & 0.226 \\
\hline GA & High & 13 & $6.82(0-26.90)$ & 12 & $8.64(0-11.58)$ & 0.511 \\
\hline AA & High & 4 & $9.99(1.27-13.10)$ & - & & \\
\hline G allele & & 34 & $2.35(0-26.9)$ & 36 & $10.81(0-64.07)$ & 0.194 \\
\hline A allele & & 17 & $7.89(0-26.9)$ & 12 & $8.64(0-11.58)$ & 0.293 \\
\hline \multicolumn{7}{|l|}{ IL-6 } \\
\hline GG & High & 27 & $3.44(0-32.35)$ & 24 & $0(0-267.38)$ & $<0.0001$ \\
\hline GC & High & 8 & $6.45(0.57-15.41)$ & 8 & $0(0-0.58)$ & $<0.0001$ \\
\hline CC & Low & 3 & $14.1(4.80-16.11)$ & 4 & 0 & 0.057 \\
\hline G allele & & 35 & $3.61(0-32.35)$ & 32 & $0(0-267.38)$ & $<0.0001$ \\
\hline C allele & & 11 & $9.52(0.57-16.11)$ & 12 & $0(0-0.58)$ & $<0.0001$ \\
\hline \multicolumn{7}{|l|}{$\mid \mathrm{L}-10$} \\
\hline GCC GCC & High & 6 & $4.99(0-11.27)$ & 7 & $0.56(0-2.03)$ & 0.031 \\
\hline GCC ACC & Intermediate & 8 & $3.61(0-7.16)$ & 6 & $1.44(0-3.38)$ & 0.090 \\
\hline GCC ATA & Intermediate & 9 & $3.48(0-9.48)$ & 8 & $0.10(0-7.56)$ & 0.077 \\
\hline ACC ACC & Low & 6 & $4.05(0-6.52)$ & 7 & $1.58(0-4.92)$ & 0.221 \\
\hline ACC ATA & Low & 3 & $2.99(0.72-3.56)$ & 4 & $1.54(0-6.74)$ & 0.721 \\
\hline ATA ATA & Low & 6 & $4.92(0.80-12.16)$ & 4 & $0.57(0-5.13)$ & 0.087 \\
\hline GCC haplotype & & 23 & $3.56(0-11.27)$ & 21 & $0.41(0-7.56)$ & 0.001 \\
\hline ACC haplotype & & 17 & $3.56(0-7.16)$ & 17 & $1.48(0-6.74)$ & 0.067 \\
\hline ATA haplotype & & 18 & $3.56(0-11.27)$ & 16 & $0.10(0-7.56)$ & 0.011 \\
\hline-1082 G allele & & 23 & $3.56(0-11.27)$ & 21 & $0.48(0-7.56)$ & $<0.0001$ \\
\hline A allele & & 32 & $3.58(0-12.16)$ & 29 & $1.09(0-7.56)$ & $<0.0001$ \\
\hline-819 C allele & & 32 & $3.56(0-11.27)$ & 32 & $1.22(0-7.56)$ & $<0.0001$ \\
\hline T allele & & 18 & $4.50(0-12.16)$ & 16 & $0.10(0-7.56)$ & 0.002 \\
\hline -592 C allele & & 32 & $3.56(0-11.27)$ & 32 & $1.22(0-7.56)$ & $<0.0001$ \\
\hline A allele & & 18 & $4.50(0-12.16)$ & 16 & $0.10(0-7.56)$ & 0.002 \\
\hline TGF- $\beta_{1}$ & & & & & & \\
\hline$\Pi \mathrm{GG}$ & High & 14 & $18.98(0-253.84)$ & 13 & $10.34(2.67-19.34)$ & 0.058 \\
\hline TC GG & High & 17 & $9.7(0.16-185.28)$ & 12 & $10.23(5.27-21.21)$ & 0.929 \\
\hline TC GC & Intermediate & 3 & $12.95(3.44-70.94)$ & 5 & $8.04(3.96-37.15)$ & 0.881 \\
\hline CC GG & Intermediate & 3 & $6.32(4.5-13.72)$ & 5 & $10.58(6.06-13.19)$ & 0.655 \\
\hline$\pi \mathrm{GC}$ & Intermediate & & - & & - & \\
\hline$C C G C$ & Low & 1 & 16.35 & 1 & 6.91 & 0.317 \\
\hline $\mathrm{CC} C \mathrm{C}$ & Low & & - & & - & \\
\hline$\Pi \mathrm{CC}$ & Low & & - & & - & \\
\hline TC CC & Low & & - & & - & \\
\hline Codon $10 \mathrm{~T}$ allele & & 34 & $14.87(0-253.84)$ & 30 & $10.34(2.67-37.15)$ & 0.023 \\
\hline C allele & & 24 & $11.32(0.16-185.28)$ & 23 & $10.11(3.96-37.15)$ & 0.949 \\
\hline Codon 25 G allele & & 38 & $13.33(0-253.84)$ & 23 & $10.34(2.67-37.15)$ & 0.067 \\
\hline C allele & & 4 & $14.65(3.44-70.94)$ & 19 & $7.47(3.96-37.15)$ & 0.670 \\
\hline
\end{tabular}

Data presented as median (range) in $\mathrm{pg} / \mathrm{ml} . \mathrm{n}=$ number of patients.

Abbreviations: TNF- $a$ tumor necrosis factor alpha, IL interleukin, and TGF- $\beta_{1}$ transforming growth factor beta.

*Nonparametric Mann-Whitney U test. 
study, we found no difference in the distribution of TNF- $\alpha$ alleles and genotypes between IPF patients and controls. However, the TNF- $\alpha$ (-308) GG genotype was significantly associated with a higher honeycombing extent score, whereas the TNF- $\alpha$ (-308) AG genotype tended to be associated with a lower honeycombing extent score. This suggests that TNF- $\alpha$ polymorphisms may play an important role in disease severity.

IFN- $\gamma$ is a Th- 1 cytokine that plays pivotal roles in modulating immune responses; it can inhibit fibroblast proliferation and has been shown to reduce extracellularmatrix deposition in animal models of fibrosis [43]. Previously, IFN- $\gamma$ was found to be decreased in the sera and lung tissues of IPF patients [25,44]. However, in agreement with the findings of Latsi et al. [45] and Vasakova et al. [8], we found no association between IFN- $\gamma$ polymorphisms and IPF in our Saudi population.

\section{Conclusion}

In conclusion, we herein identified associations between TNF- $\alpha$, IL-6, IL-10, and TGF- $\beta_{1}$ polymorphisms and $\mathrm{PaO}_{2}$, DLco, and HRCT scores in IPF patients, implying that these factors may play important roles in modulating disease severity. The TGF- $\beta_{1}$ (codons 10 and 25) CC GG genotype, which was present in a relatively small proportion of patients compared to the controls, was associated with decreased disease severity. Further studies will be needed to evaluate the potential protective effect of this genotype against severe IPF.

\section{Competing interests}

The authors declare that they have no competing interests.

\section{Authors' contributions}

EHA contributed to the design of the study and care of patients, obtained patient data, performed statistical analysis, interpreted the data and drafted the manuscript. JGC performed statistical analysis, interpreted the data and drafted the manuscript. ZC, AA, and AAA contributed to data collection and helped to draft the manuscript. All authors read and approved the final manuscript.

\section{Acknowledgments}

The authors thank Actelion Pharmaceuticals Ltd. (Riyadh, Saudi Arabia) for providing the cytokine genotyping kit and serum cytokine assay used in the present study.

The work was conducted at King Khalid University Hospital, College of Medicine, King Saud University, Riyadh 11461, Saudi Arabia.

\section{Author details \\ ${ }^{1}$ Departments of Medicine, King Saud University, Riyadh, Saudi Arabia. ${ }^{2}$ Departments of Pathology, King Saud University, Riyadh, Saudi Arabia. ${ }^{3}$ Departments of Radiology, College of Medicine, King Saud University, Riyadh, Saudi Arabia. ${ }^{4}$ Pulmonary Division, Department of Medicine (38), College of Medicine, King Saud University, P.O. Box 2925, Riyadh 11461, Saudi Arabia.}

\section{Received: 31 August 2012 Accepted: 27 June 2013}

Published: 1 July 2013

\section{References}

1. Raghu G, Collard HR, Egan JJ, Martinez FJ, Behr J, Brown KK, Colby TV, Cordier JF, Flaherty KR, Lasky JA, et al: An official ATS/ERS/JRS/ALAT statement: idiopathic pulmonary fibrosis: evidence-based guidelines for diagnosis and management. Am J Respir Crit Care Med 2011, 183(6):788-824.
2. Coker RK, Laurent GJ: Pulmonary fibrosis: cytokines in the balance. The European respiratory journal: official journal of the European Society for Clinical Respiratory Physiology 1998, 11(6):1218-1221.

3. Whyte M, Hubbard R, Meliconi R, Whidborne M, Eaton V, Bingle C, Timms J, Duff G, Facchini A, Pacilli A, et al: Increased risk of fibrosing alveolitis associated with interleukin-1 receptor antagonist and tumor necrosis factor-alpha gene polymorphisms. Am J Respir Crit Care Med 2000, 162(2 Pt 1):755-758.

4. Freeburn RW, Kendall H, Dobson L, Egan J, Simler NJ, Millar AB: The 3' untranslated region of tumor necrosis factor-alpha is highly conserved in idiopathic pulmonary fibrosis (IPF). Eur Cytokine Netw 2001, 12(1):33-38.

5. Pantelidis P, Fanning GC, Wells AU, Welsh Kl, Du Bois RM: Analysis of tumor necrosis factor-alpha, lymphotoxin-alpha, tumor necrosis factor receptor II, and interleukin-6 polymorphisms in patients with idiopathic pulmonary fibrosis. Am J Respir Crit Care Med 2001, 163(6):1432-1436.

6. Riha RL, Yang IA, Rabnott GC, Tunnicliffe AM, Fong KM, Zimmerman PV: Cytokine gene polymorphisms in idiopathic pulmonary fibrosis. Intern Med J 2004, 34(3):126-129.

7. Vasakova M, Striz I, Slavcev A, Jandova S, Dutka J, Terl M, Kolesar L, Sulc J: Correlation of IL-1alpha and IL-4 gene polymorphisms and clinical parameters in idiopathic pulmonary fibrosis. Scand J Immunol 2007, 65(3):265-270.

8. Vasakova M, Striz I, Slavcev A, Jandova S, Kolesar L, Sulc J: Th1/Th2 cytokine gene polymorphisms in patients with idiopathic pulmonary fibrosis. Tissue Antigens 2006, 67(3):229-232.

9. Xaubet A, Marin-Arguedas A, Lario S, Ancochea J, Morell F, Ruiz-Manzano J, Rodriguez-Becerra E, Rodriguez-Arias JM, Inigo P, Sanz S, et al: Transforming growth factor-beta1 gene polymorphisms are associated with disease progression in idiopathic pulmonary fibrosis. Am J Respir Crit Care Med 2003, 168(4):431-435.

10. Lynch DA, Godwin JD, Safrin S, Starko KM, Hormel P, Brown KK, Raghu G, King TE Jr, Bradford WZ, Schwartz DA, et al: High-resolution computed tomography in idiopathic pulmonary fibrosis: diagnosis and prognosis. Am J Respir Crit Care Med 2005, 172(4):488-493.

11. Alhamad EH, Al-Kassimi FA, Alboukai AA, Raddaoui E, Al-Hajjaj MS, Hajjar W, Shaik SA: Comparison of three groups of patients with usual interstitial pneumonia. Respir Med 2012, 106(11):1575-1585.

12. American Thoracic S, European Respiratory S: American Thoracic Society/ European Respiratory Society International Multidisciplinary Consensus Classification of the Idiopathic Interstitial Pneumonias. This joint statement of the American Thoracic Society (ATS), and the European Respiratory Society (ERS) was adopted by the ATS board of directors, June 2001 and by the ERS Executive Committee, June 2001. Am J Respir Crit Care Med 2002, 165(2):277-304.

13. Miller MR, Hankinson J, Brusasco V, Burgos F, Casaburi R, Coates A, Crapo R, Enright P, van der Grinten CP, Gustafsson P, et al: Standardisation of spirometry. The European respiratory journal : official journal of the European Society for Clinical Respiratory Physiology 2005, 26(2):319-338.

14. Wanger J, Clausen JL, Coates A, Pedersen OF, Brusasco V, Burgos F, Casaburi R, Crapo $R$, Enright $P$, van der Grinten $C P$, et al: Standardisation of the measurement of lung volumes. The European respiratory journal : official journal of the European Society for Clinical Respiratory Physiology 2005, 26(3):511-522.

15. Macintyre N, Crapo RO, Viegi G, Johnson DC, van der Grinten CP, Brusasco $V$, Burgos F, Casaburi R, Coates A, Enright $P$, et al: Standardisation of the single-breath determination of carbon monoxide uptake in the lung. The European respiratory journal : official journal of the European Society for Clinical Respiratory Physiology 2005, 26(4):720-735.

16. Alhamad EH, Al-Boukai AA, Al-Kassimi FA, Alfaleh HF, Alshamiri MQ, Alzeer AH, Al-Otair HA, Ibrahim GF, Shaik SA: Prediction of pulmonary hypertension in patients with or without interstitial lung disease: reliability of CT findings. Radiology 2011, 260(3):875-883.

17. Gross TJ, Hunninghake GW: Idiopathic pulmonary fibrosis. N Engl J Med 2001, 345(7):517-525.

18. Furuie $H$, Yamasaki $H$, Suga $M$, Ando M: Altered accessory cell function of alveolar macrophages: a possible mechanism for induction of Th2 secretory profile in idiopathic pulmonary fibrosis. The European respiratory journal : official journal of the European Society for Clinical Respiratory Physiology 1997, 10(4):787-794.

19. Wallace WA, Ramage EA, Lamb D, Howie SE: A type 2 (Th2-like) pattern of immune response predominates in the pulmonary interstitium of patients with cryptogenic fibrosing alveolitis (CFA). Clin Exp Immunol 1995, 101(3):436-441. 
20. Moore KW, de Waal MR, Coffman RL, O'Garra A: Interleukin-10 and the interleukin-10 receptor. Annu Rev Immunol 2001, 19:683-765.

21. Groux H, O'Garra A, Bigler M, Rouleau M, Antonenko S, de Vries JE, Roncarolo MG: A CD4+ T-cell subset inhibits antigen-specific T-cell responses and prevents colitis. Nature 1997, 389(6652):737-742.

22. Arai T, Abe K, Matsuoka H, Yoshida M, Mori M, Goya S, Kida H, Nishino K, Osaki T, Tachibana I, et al: Introduction of the interleukin-10 gene into mice inhibited bleomycin-induced lung injury in vivo. Am J Physiol Lung Cell Mol Physiol 2000, 278(5):L914-L922.

23. Huaux F, Louahed J, Hudspith B, Meredith C, Delos M, Renauld JC, Lison D: Role of interleukin-10 in the lung response to silica in mice. Am J Respir Cell Mol Biol 1998, 18(1):51-59.

24. Martinez JA, King TE Jr, Brown K, Jennings CA, Borish L, Mortenson RL, Khan TZ, Bost TW, Riches DW: Increased expression of the interleukin-10 gene by alveolar macrophages in interstitial lung disease. Am J Physiol 1997, 273(3 Pt 1):L676-L683.

25. Tsoutsou PG, Gourgoulianis Kl, Petinaki E, Germenis A, Tsoutsou AG, Mpaka M, Efremidou S, Molyvdas PA: Cytokine levels in the sera of patients with idiopathic pulmonary fibrosis. Respir Med 2006, 100(5):938-945.

26. Heinrich PC, Castell JV, Andus T: Interleukin- 6 and the acute phase response. Biochem J 1990, 265(3):621-636.

27. Akashi M, Loussararian AH, Adelman DC, Saito M, Koeffler HP: Role of lymphotoxin in expression of interleukin 6 in human fibroblasts. Stimulation and regulation. J Clin Invest 1990, 85(1):121-129.

28. Saito F, Tasaka S, Inoue K, Miyamoto K, Nakano Y, Ogawa Y, Yamada W, Shiraishi Y, Hasegawa N, Fujishima S, et al: Role of interleukin-6 in bleomycin-induced lung inflammatory changes in mice. Am J Respir Cell Mol Biol 2008, 38(5):566-571.

29. Tabata C, Kadokawa Y, Tabata R, Takahashi M, Okoshi K, Sakai Y, Mishima M, Kubo H: All-trans-retinoic acid prevents radiation- or bleomycin-induced pulmonary fibrosis. Am J Respir Crit Care Med 2006, 174(12):1352-1360.

30. Tsantes A, Tassiopoulos S, Papadhimitriou SI, Bonovas S, Kavalierou L, Vaiopoulos G, Meletis I: Suboptimal erythropoietic response to hypoxemia in idiopathic pulmonary fibrosis. Chest 2003, 124(2):548-553.

31. Collard HR, Calfee CS, Wolters PJ, Song JW, Hong SB, Brady S, Ishizaka A, Jones KD, King TE Jr, Matthay MA, et al: Plasma biomarker profiles in acute exacerbation of idiopathic pulmonary fibrosis. Am J Physiol Lung Cell Mol Physiol 2010, 299(1):L3-L7.

32. Ward PA, Hunninghake GW: Lung inflammation and fibrosis. Am J Respir Crit Care Med 1998, 157(4 Pt 2):S123-S129.

33. Khalil N, O'Connor RN, Unruh HW, Warren PW, Flanders KC, Kemp A, Bereznay $\mathrm{OH}$, Greenberg $\mathrm{AH}$ : Increased production and immunohistochemical localization of transforming growth factor-beta in idiopathic pulmonary fibrosis. Am J Respir Cell Mol Biol 1991, 5(2):155-162.

34. Bergeron A, Soler P, Kambouchner M, Loiseau P, Milleron B, Valeyre D, Hance AJ, Tazi A: Cytokine profiles in idiopathic pulmonary fibrosis suggest an important role for TGF-beta and IL-10. The European respiratory journal : official journal of the European Society for Clinical Respiratory Physiology 2003, 22(1):69-76.

35. Santana A, Saxena B, Noble NA, Gold LI, Marshall BC: Increased expression of transforming growth factor beta isoforms (beta 1, beta 2, beta 3) in bleomycin-induced pulmonary fibrosis. Am J Respir Cell Mol Biol 1995, 13(1):34-44.

36. Nakao A, Fujii M, Matsumura R, Kumano K, Saito Y, Miyazono K, Iwamoto I: Transient gene transfer and expression of Smad7 prevents bleomycininduced lung fibrosis in mice. J Clin Invest 1999, 104(1):5-11.

37. Li XX, Li N, Ban CJ, Zhu M, Xiao B, Dai HP: Idiopathic pulmonary fibrosis in relation to gene polymorphisms of transforming growth factor-beta1 and plasminogen activator inhibitor 1. Chin Med J 2011, 124(13):1923-1927.

38. Grainger DJ, Heathcote K, Chiano M, Snieder H, Kemp PR, Metcalfe JC, Carter ND, Spector TD: Genetic control of the circulating concentration of transforming growth factor type beta1. Hum Mol Genet 1999, 8(1):93-97.

39. Molina-Molina M, Lario S, Luburich P, Ramirez J, Carrion MT, Xaubet A: [Quantifying plasma levels of transforming growth factor beta1 in idiopathic pulmonary fibrosis]. Arch Bronconeumol 2006, 42(8):380-383.

40. Yong SJ, Adlakha A, Limper AH: Circulating transforming growth factorbeta(1): a potential marker of disease activity during idiopathic pulmonary fibrosis. Chest 2001, 120(1 Suppl):68S-70S.

41. Zhang K, Gharaee-Kermani M, McGarry B, Remick D, Phan SH: TNF-alpha-mediated lung cytokine networking and eosinophil recruitment in pulmonary fibrosis. J Immunol 1997, 158(2):954-959.
42. Zhang Y, Lee TC, Guillemin B, Yu MC, Rom WN: Enhanced IL-1 beta and tumor necrosis factor-alpha release and messenger RNA expression in macrophages from idiopathic pulmonary fibrosis or after asbestos exposure. J Immunol 1993, 150(9):4188-4196.

43. Narayanan AS, Whithey J, Souza A, Raghu G: Effect of gamma-interferon on collagen synthesis by normal and fibrotic human lung fibroblasts. Chest 1992, 101(5):1326-1331.

44. Majumdar S, Li D, Ansari T, Pantelidis P, Black CM, Gizycki M, du Bois RM, Jeffery PK: Different cytokine profiles in cryptogenic fibrosing alveolitis and fibrosing alveolitis associated with systemic sclerosis: a quantitative study of open lung biopsies. The European respiratory journal : official journal of the European Society for Clinical Respiratory Physiology 1999, 14(2):251-257.

45. Latsi P, Pantelidis P, Vassilakis D, Sato H, Welsh Kl, du Bois RM: Analysis of IL-12 p40 subunit gene and IFN-gamma G5644A polymorphisms in Idiopathic Pulmonary Fibrosis. Respir Res 2003, 4:6.

doi:10.1186/1471-2350-14-66

Cite this article as: Alhamad et al:: Cytokine gene polymorphisms and serum cytokine levels in patients with idiopathic pulmonary fibrosis. BMC Medical Genetics 2013 14:66.

\section{Submit your next manuscript to BioMed Central and take full advantage of:}

- Convenient online submission

- Thorough peer review

- No space constraints or color figure charges

- Immediate publication on acceptance

- Inclusion in PubMed, CAS, Scopus and Google Scholar

- Research which is freely available for redistribution

Submit your manuscript at www.biomedcentral.com/submit
C Biomed Central 